\title{
Right to Sanitation: Case Study of Indonesia
}

\author{
Devi Triasari ${ }^{\mathrm{a}^{*}}$
}

${ }^{a}$ Faculty of Law, University Adelaide, Australia.

*Corresponding author: devi.triasari@adelaide.edu.au

\section{ARTICLE INFO}

Article history

Received: June 20, 2021

Revised: July 25, 2021

Accepted: August 30, 2021

\section{Keywords}

Sanitation;

Health;

Indonesia;

\begin{abstract}
Sanitation is a basic human right which shows that someone is dignified and deserves to be respected as a human being. The international community has recognized the importance of this right. However, this right has not been explicitly recognized. This is because the legal status of the right to sanitation is unclear. The right to sanitation is derived from the "right to health" and "right to a decent standard of living". The results concluded that the fact that Indonesia is the 4th country with the largest population in the world puts Indonesia in the top 10 of the category of "country with the longest queue order of toilets" and "the country with the number of defecating in open area". International law which is often criticized for its weak enforcement in reality has been able to respond to the issue of the right to sanitation in Indonesia, mainly through 3 main mechanisms, namely reporting, country missions, and cooperation with civil Societies and NGOS. However, there are still some challenges from the three international human rights law capacities. By improving this capacity, his expectation of Goal 6 on sanitation rights can be realized by 2030 .
\end{abstract}

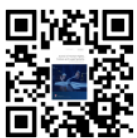

This is an open-access article under the CC-BY 4.0 license.

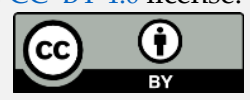

\section{Introduction}

Article 1 of The Universal Declaration of Human Rights affirms that 'all human beings are born free and equal in their dignity and rights'. Therefore human rights are the inherent and possessed rights of man from birth so often called natural rights or natural born rights. If we come from the question of why we have human rights, so the answer is simple, that is because we are human. ${ }^{1}$ The Vienna Declaration says that 'all human rights are derived from the dignity and inherent value'. Therefore, every human being has the right to live as dignified human

\footnotetext{
${ }^{1}$ Blane D. Lewis, Hieu T.M. Nguyen, and Adrianus Hendrawan, 'Political Accountability and Public Service Delivery in Decentralized Indonesia: Incumbency Advantage and the Performance of Second Term Mayors', European Journal of Political Economy, 64.May (2020), 101910 https://doi.org/10.1016/j.ejpoleco.2020.101910
} 
beings. If man lives unworthily then he loses his dignity as a human being, resulting in the loss of inherent human rights. ${ }^{2}$

The establishment of the Vienna Declaration and Program of Actions (VDPA) and OHCHR marks the successful birth of human rights which are 'universal', 'indivisible', 'interdependent and interrelated' and must be met fairly and equitably. In order to live, one needs certain feasibility conditions. Everyone needs a decent food and drink, decent clothes and housing, good health, healthy environment and so on. These needs are the standard requirements a person needs to live his life. This standard is referred to as 'a decent standard of living'. To live according to the standard of living, one that humans need is voiding feces. Sanitation is a matter of a personal nature and is closely related to human dignity. ${ }^{3}$

Yet, the reality is opposite. Perhaps, for people in developing countries, flushing a toilet and turning on a tap is taken for granted, but not for developing countries and underdeveloped countries. Not all people have the right to sanitation which is the basic right. Based on data compiled from the World Health Organization (WHO) in 2015, 1.9 billion people still use sanitation services linked to sewers that are expected to contaminate waterways. A total of ' 2.3 billion people do not have basic sanitation'. More ironic is that 892 million people still defecate in open places, such as in bushes, open water, and in ditches. Other facts are also collected by WHO and UNICEF that $19 \%$ of health care facilities in 'low income and middle-income countries', $53 \%$ of people in South Asia, $70 \%$ of people in Sub-Saharan Africa, and $46 \%$ of schools in developing countries do not have toilets. ${ }^{4}$

The poor facts about this right of sanitation have a negative impact on other basic rights, namely the right to water. Dirt which is not managed securely can contaminate the source of water, so it will result in water pollution. Poor sanitation will contribute to the transmission of diseases such as cholera, diarrhea, dysentery, hepatitis A, typhoid and polio. Inadequate sanitation is estimated to cause 280,000 diarrheal deaths per year and is a major factor in some worms, schistosomiasis, and trachoma. Poor sanitation also contributes to malnutrition. Not only that, poor sanitation is also a source of violations of women's rights in

\footnotetext{
${ }^{2}$ Lisa Cameron, Susan Olivia, and Manisha Shah, 'Scaling up Sanitation: Evidence from an RCT in Indonesia', Journal of Development Economics, 138.November 2018 (2019), 1-16 https://doi.org/10.1016/j.jdeveco.2018.12.001

${ }^{3}$ Thomas A. Birtch and others, 'Am I Choosing the Right Career? The Implications of COVID-19 on the Occupational Attitudes of Hospitality Management Students', International Journal of Hospitality Management, 95.April (2021), 102931 https://doi.org/10.1016/j.ijhm.2021.102931

4 Vladimíra Kantorová, 'Unintended Pregnancy and Abortion: What Does It Tell Us about Reproductive Health and Autonomy?', The Lancet Global Health, 8.9 (2020), e1106-7 https://doi.org/10.1016/S2214-109X(20)30342-9
} 
the Committee on the Elimination of Discrimination against Women (CEDAW) and children's rights in the Convention on the Rights of the Child (CRC). ${ }^{5}$

As many as 800 women around the world die of pregnancy and childbirth. One cause is sepsis, a condition in which the body cannot cope with severe infections. In South Asia, about 14\% of maternal deaths occur due to sepsis. This fact is much different than that of women who gave birth in developed countries. Besides, poor sanitation also causes diarrhea disease that can kill more than 314,000 toddlers each year. ${ }^{6}$

Indonesia, as the 4th position with the largest population in the world, is also experiencing the same thing. Indonesia is also included as the top 10 countries with the worst sanitation, especially in Jakarta, as a capital city in Indonesia. The high flow of urbanization makes the recognition of the right to sanitation more and more neglected. Jakarta, which has 10 million people, is filled with many slums such as Muara Angke. The World Bank's Water and Sanitation Program in 2008 indicates that poor sanitation causes at least '120 million diseases and 50,000 deaths per year' ${ }^{7}$

The above facts lead to the conclusion that recognition of human rights over sanitation is an important point in international human rights law enforcement. Because of its urgency, human rights over sanitation became an international agenda. Especially after sanitation has gained international recognition, everyone has to obtain the right to sanitation because it has been targeted by 2030. However, no international treaty explicitly provides a special space for the right to sanitation, there are only a few refers to the right to water. Because it is not explicitly acknowledged, this raises a debate on the status of the right to sanitation itself. Although there have been various debates about the legality of this basic right, the High Commissioner has given consideration to the importance of recognizing sanitation rights as a human right. ${ }^{8}$

\section{Results and Discussion}

\subsection{Status of the Right to Sanitation}

Resolutions of the United Nations General Assembly and Human Rights Council in 2016 stated that the right to water and the right to sanitation are two

\footnotetext{
${ }^{5}$ Jonathan Bearak and others, 'Unintended Pregnancy and Abortion by Income, Region, and the Legal Status of Abortion: Estimates from a Comprehensive Model for 1990-2019', The Lancet Global Health, 8.9 (2020), e1152-61 https://doi.org/10.1016/S2214-109X(20)30315-6

${ }^{6}$ Arnold Japutra and Ringkar Situmorang, 'The Repercussions and Challenges of COVID-19 in the Hotel Industry: Potential Strategies from a Case Study of Indonesia', International Journal of Hospitality Management, 95.December 2020 (2021), 102890 https://doi.org/10.1016/j.ijhm.2021.102890

${ }^{7}$ Melissa Giesbrecht and others, "“We Are to Be like Machines...fill the Bed before It Gets Cold": Exploring the Emotional Geographies of Healthcare Providers Caring for Dying Residents in LongTerm Care Facilities', Social Science and Medicine, 272 (2021), 113749 https://doi.org/10.1016/j.socscimed.2021.113749

8 Japutra and Situmorang.
} 
separate rights. Mr. Léo Heller, who is a Special Rapporteur on the human rights to safe drinking water and sanitation, discusses three reasons for the differences between rights to water and the right to sanitation. The first relates to the legal basis of those rights. When we consider the right to sanitation, we can identify strong relationships with other rights, such as the right to health, gender equality, and decent housing. ${ }^{9}$

Especially considering the right to health, lack of sanitation has serious consequences on human health. The second reason for supporting this difference is because of the importance of specific criteria for the right to sanitation, which does not apply to the right to water. In particular, privacy and dignity are two specific components of the right to sanitation. That is, lack of adequate sanitation can greatly affect the privacy of individuals-especially women and girls. This is in harmony with the fact that the dangers of poor sanitation for women who are naturally diverse have different risks associated with the importance of sanitation. A third reason is that sanitation has traditionally been underfed priority over water. The world deficit for sanitation is far greater than the water access deficit. About 2, 5 billion people still do not have access to sanitation improvements. That's about 4 times more than the number of people without access to better water sources. ${ }^{10}$

Others argue that the right to water and the right to sanitation are complementary rights. The view that water rights and the right to sanitation should be distinguished because sanitation has no link to water cannot simply be accepted. The total separation between right to sanitation and right to water is not recommended because in international practice, it is irrational. The right to water and the right to sanitation are closely related in a 'normative', by 'matter-of-fact manner' and also based on the 'same legal basis'. In practice, it is impossible to provide clean water without proper sanitation management. This means that the right to sanitation always has a direct impact on the right to water. ${ }^{11}$

However, both rights have not been adequately addressed and especially the right to sanitation has long been neglected. The second status of this right has not been fully answered and still creates confusion. Right to sanitation is considered to have a unique status because it is considered a right closely related to the right to water. It does not matter whether to stand as a right or join the right to water. The most important thing is the explicit recognition of the right to sanitation in

${ }_{9}$ M. Tinoco and others, 'Water Co-Operation between Cultures: Partnerships with Indigenous Peoples for Sustainable Water and Sanitation Services', Aquatic Procedia, 2 (2014), 55-62 https://doi.org/10.1016/j.aqpro.2014.07.009

10 S. Ravet and A. Braïlowsky, 'Utilities' Contribution to the Human Right to Water and Sanitation: Importance of Stakeholders' Ownership', Aquatic Procedia, 2 (2014), 70-78 https://doi.org/10.1016/j.aqpro.2014.07.011

11 Mícheál de Barra and others, 'Understanding Infection Prevention Behaviour in Maternity Wards: A Mixed-Methods Analysis of Hand Hygiene in Zanzibar', Social Science and Medicine, 272.December 2020 (2021) https://doi.org/10.1016/j.socscimed.2020.113543 
international treaties. Currently the right to sanitation appears in General Assembly Resolution 64/292. ${ }^{12}$

However, the legal status of the General Assembly Resolution is still questionable. With the regulation of the right to sanitation using a separate international treaty, it will be more binding on the state party. In addition, if the right to sanitation under international treaties, the state will feel obliged to report on the enforcement of the right to sanitation more clearly. Moreover, until now there has been no regulation on how good sanitation standards as those found on water rights, such as 'sufficient, safe, acceptable, physically accessible, and affordable'. With the regulation of the right to sanitation in international treaties, it will be clear on the legal status of sanitation and the essential elements which are the state standards for enforcing sanitation on citizens. ${ }^{13}$

\subsection{The Evolution of the Rights to Sanitation in International Human Rights}

In the Universal Declaration of human rights it is not explicitly stated about the right to sanitation. Nevertheless, the concept of human rights is a dynamic concept; it continues to move along with the development of civilization. When it is realized that the right to sanitation is crucial, it is important to affirm that the right to sanitation is a human right. ${ }^{14}$

The right to sanitation is a dimension of rights sourced from 'the right to an adequate standard of living' and 'the right to health'. In the Universal Declaration of Human Rights, this right is affirmed in Article 25 of the Universal Declaration as follows everyone is entitled to an adequate standard of living for the health and well-being of himself and his family, including the right to food, clothing, shelter, and health care, necessary social services, and the right to security in the event of unemployment, sickness, disability, abandonment by partner, elderly, or other circumstances that lead to a decline in the level of life that occurs outside of his power. ${ }^{15}$

The Universal Declaration of Human Rights is a declaration containing human rights. This declaration is a common standard of success for all peoples and the whole nation (common standards of achievement for all peoples and all nations). This declaration is universal, applies equally to everyone, at any time, in

${ }^{12} \mathrm{H}$. Muller, 'The South African Experience on Legal, Institutional and Operational Aspects of the Rights to Water and Sanitation', Aquatic Procedia, 2 (2014), 35-41 https://doi.org/10.1016/j.aqpro.2014.07.006

${ }^{13}$ Arun S. Hendi, Irma T. Elo, and Pekka Martikainen, 'The Implications of Changing Education Distributions for Life Expectancy Gradients', Social Science and Medicine, 272 (2021), 113712 https://doi.org/10.1016/j.socscimed.2021.113712

14 A. H. Rotteveel and others, 'Societal Views in the Netherlands on Active Disinvestment of Publicly Funded Healthcare Interventions', Social Science and Medicine, 272 (2021), 113708 https://doi.org/10.1016/j.socscimed.2021.113708

15 Lisa C. Smith and Lawrence Haddad, 'Reducing Child Undernutrition: Past Drivers and Priorities for the Post-MDG Era', World Development, 68.1 (2015), 180-204 https://doi.org/10.1016/j.worlddev.2014.11.014 
different parts of the world. Every United Nations (UN) member has pledged (through the UN Charter) to progress in respect for human rights and fundamental freedoms. As a universal standard of value, the Universal Declaration of Human Rights provides guidance on how Human Rights are respected, protected and fulfilled by the countries of the world. ${ }^{16}$

The rights contained in the Universal Declaration of Human Rights are further elaborated in the International Covenant on Civil and Political Rights and the International Covenant on Economic, Social and Cultural Rights. Both of the Covenants are international treaties in which every country has an opportunity and is encouraged to commit itself to submitting to the treaty by ratifying it. Currently, Indonesia has ratified both Covenants. Indonesia ratified the Covenant on Economics, Social and Cultural Rights through Law No. 11 Year 2005 the Covenant on Civil and Politics through Law No. 12 of 2005 on the Ratification of the International Covenant on Civil and Political Rights. ${ }^{17}$

Article 11 Paragraph (1) of the Covenant on Economics, Social and Cultural Rights provides an elaboration on the right to an adequate standard of living (as intended in Article 25 of the Universal Declaration of Human Rights) as follows the states parties to the present covenant recognize the right of everyone to an adequate standard of living for himself and his family, including food, clothing and housing, and on the improvement of living conditions continuously. States Parties shall take adequate measures to ensure the realization of this right by recognizing the importance of international cooperation based on voluntary agreements. Subsequently, Article 12 Paragraph (1) of the Covenant on Economics, Social and Cultural Rights defines the right to an adequate standard of living and the right to health (as defined in Article 25 of the Universal Declaration of Human Rights) as follows: 'The States Parties to the present Covenant recognize the right of everyone to the enjoyment of the highest attainable standard of physical and mental health.' ${ }^{18}$

In order to provide explanations and official interpretations of the relevant covenants, the relevant committees/councils such as the Human Rights Council and the Committee on Economic, Social, and Cultural Rights shall issue General Comment on certain procedures, guidelines or provisions of those covenants. Although it is considered a soft law because it is not an international agreement. Yet, it is composed by an official body with in-depth and authoritative studies so

16 Elana Nightingale and Chantelle A.M. Richmond, 'Reclaiming Mountain Lake: Applying Environmental Repossession in Biigtigong Nishnaabeg Territory, Canada', Social Science and Medicine, 272 (2021), 113706 https://doi.org/10.1016/j.socscimed.2021.113706

17 Gordon McGranahan, 'Realizing the Right to Sanitation in Deprived Urban Communities: Meeting the Challenges of Collective Action, Coproduction, Affordability, and Housing Tenure', World Development, 68 (2015), 242-53 https://doi.org/10.1016/j.worlddev.2014.12.008

18 Shatha Elnakib and others, 'Providing Care under Extreme Adversity: The Impact of the Yemen Conflict on the Personal and Professional Lives of Health Workers', Social Science and Medicine, 272.February (2021), 113751 https://doi.org/10.1016/j.socscimed.2021.113751 
that it can serve as a guideline for understanding, interpreting and implementing the Covenant on Civil and Politics and Covenant on Economics, Social and Cultural Rights. ${ }^{19}$

According to General Comment No. 15 on the Right to Water, the word "included" in Article 11 paragraph (1) of the Covenant on Economics, Social and Cultural Rights in a decent standard of living is not a restricted Article 11 paragraph 1 The Covenant on Economics, Social and Cultural Rights establishes a number of rights derived from, and is required for, the realization of the right to an adequate standard of living "including adequate food, clothing and housing." The use of the word "include" indicates that the list of those rights not intended to be a limited list. The right to sanitation clearly belongs to the category of essential guarantees to ensure a decent standard of living, especially since sanitation is one of the essential conditions for supporting one's life. Furthermore, the Committee has previously acknowledged that water is a Human Right which includes Article 11 paragraph (1) (see General Comment No. 6 (1995). ${ }^{20}$

Further General Comment No. 15 also explains that the right to water is an inalienable right in relation to the right to achieve the highest standards of health (and the right to adequate housing and food) and a bridge to other rights, as follows the right to water is an inalienable right in relation to the right to achieve the highest standard of health (Article 12 paragraph 1) and the right to adequate housing and adequate food (Article 11 paragraph 1). The right should also be seen as a bridge to other rights contained in the International Bill of Human Rights, especially the right to life and human dignity. ${ }^{21}$

Based on the above description, the right to sanitation is closely linked to an adequate standard of living and health. This General Comment has provided an initial guidance on how this right to sanitation has a legitimate basis for being a Human Right attached to humanity on the one hand. On the other hand is the obligation of States to respect, protect and fulfill this right. However, this General Comment does not specifically set forth how this sanitation hazard so interpretation depends on each country. ${ }^{22}$

In further developments, on November 27, 2006, the UN Human Rights

19 J.H. Matthews and others, 'More than the Fish: Environmental Flows for Good Policy and Governance, Poverty Alleviation and Climate Adaptation', Aquatic Procedia, 2 (2014), 16-23 https://doi.org/10.1016/j.aqpro.2014.07.004

${ }^{20}$ Getaw Tadesse and Godfrey Bahiigwa, 'Mobile Phones and Farmers' Marketing Decisions in Ethiopia', World Development, 68 (2015), 296-307 https://doi.org/10.1016/j.worlddev.2014.12.010

${ }^{21}$ Daniella Hult Khazaie, Clifford Stott, and Sammyh S. Khan, 'Mass Meets Mosh: Exploring Healthcare Professionals' Perspectives on Social Identity Processes and Health Risks at a Religious Pilgrimage and Music Festivals', Social Science and Medicine, 272 (2021), 113763 https://doi.org/10.1016/j.socscimed.2021.113763

22 Michael Schnegg and Theresa Linke, 'Living Institutions: Sharing and Sanctioning Water among Pastoralists in Namibia', World Development, 68 (2015), 205-14 https://doi.org/10.1016/j.worlddev.2014.11.024 
Council issued Resolution No. 2/104 on Human Rights and Access to Water requests that the Office of the UN High Commissioner for Human Rights conduct a detailed review of human rights obligations related to fair access to safe drinking water and sanitation. In 2006, the Sub-Commission on the Promotion and Protection of Human Rights built on the Work of the Committee, adopting the Guidelines for the Realization of the Right to Drinking Water and Sanitation. This in-depth review was followed up by the United Nations High Commissioner for Human Rights Report on the Scope and Content of the Relevant Human Rights obligation relating to Fair Access to Clean Water and Sanitation under International Human Rights Instruments on August 16, 2007. Then in September 2008, the United Nations High Commissioner for Human Rights appointed Catarina de Albuquerque as an Independent Expert on the Issue of Human Rights Obligations Related to Access to Safe Drinking Water and Sanitation and one year later submitted his report. ${ }^{23}$

Subsequently, on 28 July 2010 the United Nations General Assembly agreed to issue Resolution No. 64/292 which recognizes that the right to safe and clean drinking water and sanitation are human rights. On September 30, 2010, the UN Human Rights Council approved the resolution HRC res 15/9. Taking into account these developments, the Human Rights Council, in March 2011, extended the mandate on water and sanitation, and changed its title to Special Rapporteur on the human rights to safe drinking water and sanitation. ${ }^{24}$

From the description above, it shows that the concept of Human Rights develop dynamically to follow the development of the need for reform values that are considered to provide benefits for human civilization. At the beginning of the formation of the Universal Declaration of Human Rights (UDHR), the right to sanitation has not been explicitly referred to as Human Rights; it is more because many people have understood that the right to sanitation is inherent to the right to water. As well as the air which is fundamental to human life, so mentioning the right to water and sanitation as a separate right is considered a repetition. But time has changed, humans need sanitation to live but with the fact that development in the world increasingly complicates the right to sanitation, an explicit recognition of the right to sanitation is needed for the state to follow.

\subsection{Case Study of this "Right" to Sanitation: Indonesia}

Indonesia is currently experiencing rapid urbanization, with cities growing faster than other Asian countries. By 2025 it is expected that $67.5 \%$ of the country's population will live in cities. Challenges come with high levels of urbanization.

${ }^{23}$ R.A. McDonnell and others, 'Impacting Policy: Harnessing Science on Climate Change and Water through Partnerships with Decision-Makers in the Middle East and North Africa Reflections', Aquatic Procedia, 2 (2014), 3-8 https://doi.org/10.1016/j.aqpro.2014.07.002

${ }^{24}$ Ian Ross and others, 'How Does Sanitation Influence People's Quality of Life? Qualitative Research in Low-Income Areas of Maputo, Mozambique', Social Science and Medicine, 272.January (2021), 113709 https://doi.org/10.1016/j.socscimed.2021.113709 
One of them is to meet the needs of the management of good sanitation facilities. The high population always has a close relationship with poor sanitation. This also happened in Indonesia where the high population and the high level of urbanization bring to the fact that Indonesia occupies the top 10 position as a country with longest queues for toilets and countries with the largest number of defecating in the open areas. ${ }^{25}$

Table 1 shows the position of Indonesia as a 4rd country in terms of queuing for toilets. While Table 2 shows the position of Indonesia as the country with the 10th highest in the number of people who defecate in the open area. 51 million residents of about 200 million Indonesians still defecate indiscriminately.

Table 1

Top Ten Places with the Longest Queues for Toilets

\begin{tabular}{cll}
\hline No & Country & $\begin{array}{l}\text { Number of people without access to 'improved' private } \\
\text { toilets (2015) }\end{array}$ \\
\hline $\mathbf{1}$ & India & $774,222,300$ \\
\hline $\mathbf{2}$ & China & $329,851,200$ \\
\hline $\mathbf{3}$ & Nigeria & $130,387,500$ \\
\hline $\mathbf{4}$ & Indonesia & $100,168,400$ \\
\hline $\mathbf{5}$ & Ethiopia & $71,217,200$ \\
\hline $\mathbf{6}$ & Pakistan & $68,666,800$ \\
\hline $\mathbf{7}$ & Bangladesh & $63,267,800$ \\
\hline $\mathbf{8}$ & Democratic Republic & $50,833,300$ \\
& of the Congo & \\
\hline $\mathbf{9}$ & Tanzania & $44,159,400$ \\
\hline $\mathbf{1 0}$ & Russian Federation & $39,468,700$ \\
\hline
\end{tabular}

Table 2

Most People Defecating in the Open, Per Square km

\begin{tabular}{|lll} 
No & \multicolumn{1}{c}{ Country } & Number Practicing Open Defecation (2015) \\
\hline 1. & India & $569,397,200$ \\
\hline 2. & Haiti & $2,011,100$ \\
\hline 3. & Togo & $3,710,000$ \\
\hline 4. & Nepal & $8,973,700$ \\
\hline 5. & Benin & $5,800,200$ \\
\hline 6. & Nigeria & $46,017,300$ \\
\hline 7. & Cambodia & $7,439,800$ \\
\hline . & Burkina Faso & $9,876,500$ \\
\hline 9. & Pakistan & $25,100,200$ \\
\hline 10. & Indonesia & $52,252,400$ \\
\hline
\end{tabular}

${ }_{25}$ Patricia J. Lopez and Abigail H. Neely, 'Fundamentally Uncaring: The Differential MultiScalar Impacts of COVID-19 in the U.S', Social Science and Medicine, 272.January (2021), 113707 https://doi.org/10.1016/j.socscimed.2021.113707 
The reality of poor sanitation in Indonesia should not to be underestimated. This is because inadequate sanitation has an impact on Indonesia's economic growth. A recent World Bank report states that Indonesia's poor sanitation currently accounts for a loss of 2.3 percent of GDP per year, in terms of associated economic and environmental losses. Wildan Setiabudi from UNICEF WASH also said that from the World Bank survey results in 2008, it is known that poor sanitation has inflicted Indonesia for Rp56 trillion losses. ${ }^{26}$ Not all domestic laws of a country are able to accommodate every problem that exists. This is where the beginning of international law emerges. Although international law is often criticized for not having the force of law, the existing international body should not be underestimated. This international body in upholding international human rights law has 3 important roles, namely reporting, country mission, cooperation with civil society and NGOS. ${ }^{27}$

Indonesia ratified ICESCR on 28 October 2005. Yet, Indonesia submitted the initial report on 29 October 2012. Basically, all existing international treaties require States parties to submit initial reports and periodic reports, including ICESCR. When we review the Indonesian report, the discussion about right to water and sanitation is in page 41 . The contents briefly state how Indonesia meets ICESCR especially in right to water and sanitation. Indonesia regulates this right into Constitution in article 33 paragraphs 3 and Law no. 7 of 2004. In the report, Indonesia stated that Indonesia has made improvements on the right to sanitation so that access to sanitation facilities increases. In 2000 the increase of 32.73\%, then in 2006 increased by 35.03\%, and in 2010 increased by $55.53 \%$. This increase is quite significant. However, when looking at the reality on the ground, there are many lack of access to sanitation..$^{28}$

The thing that writers consider is when a state sends out both initial and periodic reports, is the actually sufficient to provide accurate data on the fulfillment of its obligations under treaties? It seems that most will only convey the various theories and laws of the country, compared to the concrete facts in the field on the fulfillment of their obligations. Concluding observation on Indonesia was given on June 18, 2014. The Committee's requested the Indonesian government to increase compliance with water and improve sanitation facilities. The Committee emphasis on the fulfillment of these two rights, especially in rural

${ }^{26}$ Sanne Siete Visser and Hinke Haisma, 'Fulfilling Food Practices: Applying the Capability Approach to Ethnographic Research in the Northern Netherlands', Social Science and Medicine, 272.January (2021), 113701 https://doi.org/10.1016/j.socscimed.2021.113701

${ }^{27}$ Elizabeth McGill and others, 'Evaluation of Public Health Interventions from a Complex Systems Perspective: A Research Methods Review', Social Science and Medicine, 272 (2021), 113697 https://doi.org/10.1016/j.socscimed.2021.113697

28 Q. Zhu and Y. Li, 'Environmental Restoration in the Shiyang River Basin, China: Conservation, Reallocation and More Efficient Use of Water', Aquatic Procedia, 2.september 2013 (2014), 24-34 https://doi.org/10.1016/j.aqpro.2014.07.005 
areas. The Committee requested the Indonesian government to refer to the General Comment No. 15 in enforcing its obligations..$^{29}$

The Special Rapporteur visits the country to examine sanitation situations at the national level, identify practices that have been undertaken by the state, and provide recommendations to States parties on measures to improve access and ensure sanitation compliance. ${ }^{30}$ Here are the country missions conducted by The Special Rapporteur from 2009 to 2017:

Table 3

The Country to Examine Sanitation Situations at the National Level

\begin{tabular}{|c|c|c|}
\hline No & Country & Mission Dates \\
\hline 1. & Costa Rica & 19-27 March 2009 \\
\hline 2. & Egypt & 21-28 June 2009 \\
\hline 3. & Bangladesh & 3-10 December 2009 \\
\hline 4. & Slovenia & 24-28 May 2010 \\
\hline 5. & Japan & 20-28 July 2010 \\
\hline 6. & United States of America & 22 February to 4 March 2011 \\
\hline 7. & Namibia & 4-11 July 2011 \\
\hline 8. & Senegal & 14-21 November 2011 \\
\hline 9. & Uruguay & 13-17 February 2012 \\
\hline 10. & Tuvalu & 17-19 July 2012 \\
\hline 11. & Kiribati & 23-26 July 2012 \\
\hline 12. & Thailand & 1-8 February 2013 \\
\hline 13. & Brazil & 9-19 December 2013 \\
\hline 14. & Jordan & 11-16 March 2014 \\
\hline 15. & Kenya & 22-28 July 2014 \\
\hline 16. & Tajikistan & 4-12 August 2015 \\
\hline 17. & Botswana & 9-17 November 2015 \\
\hline 18. & El Salvador & 11-18 May 2016 \\
\hline 19. & Portugal & 5-13 December 2016 \\
\hline 20. & Mexico & 2-12 May 2017 \\
\hline
\end{tabular}

Starting from 2009 up to now, there are 20 country visits that have been done by The Special Rapporteur. This is unique because the recognition of rights to sanitation through General Assembly Resolution 64/292 was in 2010, one year after the first country mission. This fact shows the success of international human rights law in its capacity to initiate better human rights enforcement. This demonstrates how this existing international human rights law is instrumental in the development of existing human rights. However, what seems a bit strange is that

${ }_{29}$ M.G. Eriksson, L.J. Gordon, and J. Kuylenstierna, 'Cross-Sectoral Approaches Help Build Water Resilience - Reflections', Aquatic Procedia, 2 (2014), 42-47 https://doi.org/10.1016/j.aqpro.2014.07.007

${ }^{30}$ Fiona A. Stevenson and others, 'Combining Patient Talk about Internet Use during Primary Care Consultations with Retrospective Accounts. A Qualitative Analysis of Interactional and Interview Data', Social Science and Medicine, $272 \quad$ (2021), 113703 https://doi.org/10.1016/j.socscimed.2021.113703 
the country missions seem random in practice. Why are the country missions not done in countries with the worst sanitation first so that the country mission will be more right on targeting? It seems that we need to find out the background of The Special Rapporteur in choosing the country of destination for this country missions.

International human rights laws will not achieve success without the support of other factors, such as the role of civil society and NGOS that are practically closer to the community. For example, when the presence of civil society and NGOS became the cause of the state's compliance with the international treaties it ratified. ${ }^{31}$ In fact, this factor is very influential on the compliance of the state in the fulfillment of human rights standards. Cooperation with civil society and NGOS is divided into multilateral cooperation and bilateral cooperation. ${ }^{32}$

From the above explanation, it appears that the capacities of International Human Rights Law are reporting, country mission, and corporation with civil society and NGO's. But in order to reach the New Global Goal by 2030, especially on Goal 6, namely water, sanitation, and hygiene for all, real improvement steps are needed to achieve it. The 13-year time is not easy to make a difference to the world. Without a unified collaboration, it would not be possible to achieve this ideal world. ${ }^{33}$

In term of reporting capacity, the problem of a country's ability to send a report is common. However, the long time to produce the Concluding Observation from the committee also seems to be immediately addressed. All countries will surely take on the Committee's role model, it would be better if Committee were more responsive to the state party's report, for example in the case of Indonesia. Although many people have doubts about the reporting system in the UN, at least there have been many benefits in this reporting system, for example, making the country will feel ashamed if not immediately send a report so that will be ostracized in international relations. In addition, the recognition of sanitation as a right is essential so that a treaty should be made. By giving a clear recognition of the right to sanitation as a separate right, it will make it easier for the reporting system because it no longer lies with the ICESCR. ${ }^{34}$

In terms of country mission, the writer is still wondering why the country mission destinations are not the countries which occupy the top 10 worst position first. The Committee is seen making random visits, either to countries with poor

31 P. Morgan, 'Beneficial Partnerships in Rural Water Supply and Sanitation - Reflections', Aquatic Procedia, 2 (2014), 63-69 https://doi.org/10.1016/j.aqpro.2014.07.010

${ }_{32}$ M.J. Patrick and others, 'Building Bridges between the Sciences and the Arts of Water CoOperation through Collective Action - Reflections', Aquatic Procedia, 2 (2014), 48-54 https://doi.org/10.1016/j.aqpro.2014.07.008

33 Marta Caserotti and others, 'Associations of COVID-19 Risk Perception with Vaccine Hesitancy over Time for Italian Residents', Social Science and Medicine, 272.January (2021), 113688 https://doi.org/10.1016/j.socscimed.2021.113688

34 Bearak and others. 
sanitation or to developed countries with improved sanitation. According to the authors' view, it would be better if the country missions were really focused first on the top 10 countries with the worst sanitation. However, according to Goal 6, we must fight against poverty everywhere, including in this case providing sanitation to everyone in the world. ${ }^{35}$

In terms of corporation with civil society and NGO's, this is a concrete step that contributes significantly. Whether through multilateral corporations or bilateral corporations, it is clear how these corporations have a tremendous impact on a country's struggle for sanitation. It would be better if the NGOS involved did not only come from foreign cooperation. The author considers the necessity of the Committee issuing the latest recommendations for each country to make domestic legislation to the village level. For example, in this case in Indonesia. With decentralized system in Indonesia, Indonesia's central government needs to establish village-level legislation requiring each village head to build a toilet for existing villagers. Each village government can allocate existing village funds to make one toilet. This is certainly easier than if the central government in Indonesia should think about the hundreds or thousands of toilets that must be built. Or a second alternative that can be taken is to provide arrangements to companies in Indonesia to provide CSR in the form of toilet. Think of one company in the region building one toilet as CSR, certainly home work against right to sanitation can be resolved soon. And in the next 13 years the Goal 6 can be achieved well, in the world at large, and in Indonesia in particular.

\section{Conclusion}

Based on the results of the discussion in the previous chapter, it can be concluded that sanitation is a basic human right which shows that someone is dignified and deserves to be respected as a human being. The international community has recognized the importance of this right. However, this right has not been explicitly recognized. This is because the legal status of the right to sanitation is unclear. The right to sanitation is derived from the "right to health" and "right to a decent standard of living". Since the right to sanitation does not have its own space in international law, this has resulted in this right being connected with water. This raises a dualism of the idea whether the right to sanitation can stand on its own whether to join the right to water. However, whatever it is, the most important thing is to give explicit recognition of the right to sanitation in international treaties binding countries to facilitate the monitoring and execution of obligations by the state. There is only General Assembly Resolution no. 64/292 which does not bind countries to comply. The fact that Indonesia is the 4th country with the largest population in the world puts Indonesia in the top 10 of the category of "country with the longest queue order of toilets" and "the country with the number of defecating in open area".

${ }^{35}$ Smith and Haddad. 
International law which is often criticized for its weak enforcement in reality has been able to respond to the issue of the right to sanitation in Indonesia, mainly through 3 main mechanisms, namely reporting, country missions, and cooperation with civil Societies and NGOS. However, there are still some challenges from the three international human rights law capacities. By improving this capacity, his expectation of Goal 6 on sanitation rights can be realized by 2030 .

\section{References}

Bearak, Jonathan, Anna Popinchalk, Bela Ganatra, Ann Beth Moller, Özge Tunçalp, Cynthia Beavin, and others, 'Unintended Pregnancy and Abortion by Income, Region, and the Legal Status of Abortion: Estimates from a Comprehensive Model for 1990-2019', The Lancet Global Health, 8.9 (2020), e1152-61 https://doi.org/10.1016/S2214-109X(20)30315-6

Birtch, Thomas A., Flora F.T. Chiang, Zhenyao Cai, and Jin Wang, 'Am I Choosing the Right Career? The Implications of COVID-19 on the Occupational Attitudes of Hospitality Management Students', International Journal of Hospitality Management, 95.April (2021), 102931 https://doi.org/10.1016/j.ijhm.2021.102931

Cameron, Lisa, Susan Olivia, and Manisha Shah, 'Scaling up Sanitation: Evidence from an RCT in Indonesia', Journal of Development Economics, 138. November 2018 (2019), 1-16 https://doi.org/10.1016/j.jdeveco.2018.12.001

Caserotti, Marta, Paolo Girardi, Enrico Rubaltelli, Alessandra Tasso, Lorella Lotto, and Teresa Gavaruzzi, 'Associations of COVID-19 Risk Perception with Vaccine Hesitancy over Time for Italian Residents', Social Science and Medicine, 272.January (2021), 113688 https://doi.org/10.1016/j.socscimed.2021.113688

De Barra, Mícheál, Giorgia Gon, Susannah Woodd, Wendy J. Graham, Marijn de Bruin, Catherine Kahabuka, and others, 'Understanding Infection Prevention Behaviour in Maternity Wards: A Mixed-Methods Analysis of Hand Hygiene in Zanzibar', Social Science and Medicine, 272.December 2020 (2021) https://doi.org/10.1016/j.socscimed.2020.113543

Elnakib, Shatha, Sarah Elaraby, Fouad Othman, Huda BaSaleem, Nagiba A. Abdulghani AlShawafi, Iman Ahmed Saleh Al-Gawfi, and others, 'Providing Care under Extreme Adversity: The Impact of the Yemen Conflict on the Personal and Professional Lives of Health Workers', Social Science and Medicine, 272.February (2021), 113751 https://doi.org/10.1016/j.socscimed.2021.113751

Eriksson, M.G., L.J. Gordon, and J. Kuylenstierna, 'Cross-Sectoral Approaches Help Build Water Resilience - Reflections', Aquatic Procedia, 2 (2014), 42-47 https://doi.org/10.1016/j.aqpro.2014.07.007 
Giesbrecht, Melissa, Kelli I. Stajduhar, Denise Cloutier, and Carren Dujela, “"We Are to Be like Machines...fill the Bed before It Gets Cold": Exploring the Emotional Geographies of Healthcare Providers Caring for Dying Residents in Long-Term Care Facilities', Social Science and Medicine, 272 (2021), 113749 https://doi.org/10.1016/j.socscimed.2021.113749

Hendi, Arun S., Irma T. Elo, and Pekka Martikainen, 'The Implications of Changing Education Distributions for Life Expectancy Gradients', Social $\begin{array}{llll}\text { Science and } & \text { Medicine, } & 272\end{array}$ https://doi.org/10.1016/j.socscimed.2021.113712

Hult Khazaie, Daniella, Clifford Stott, and Sammyh S. Khan, 'Mass Meets Mosh: Exploring Healthcare Professionals' Perspectives on Social Identity Processes and Health Risks at a Religious Pilgrimage and Music Festivals', Social Science and Medicine, 272 (2021), 113763 https://doi.org/10.1016/j.socscimed.2021.113763

Japutra, Arnold, and Ringkar Situmorang, 'The Repercussions and Challenges of COVID-19 in the Hotel Industry: Potential Strategies from a Case Study of Indonesia', International Journal of Hospitality Management, 95.December 2020 (2021), 102890 https://doi.org/10.1016/j.ijhm.2021.102890

Kantorová, Vladimíra, 'Unintended Pregnancy and Abortion: What Does It Tell Us about Reproductive Health and Autonomy?', The Lancet Global Health, 8.9 (2020), e1106-7 https://doi.org/10.1016/S2214-109X(20)30342-9

Lewis, Blane D., Hieu T.M. Nguyen, and Adrianus Hendrawan, 'Political Accountability and Public Service Delivery in Decentralized Indonesia: Incumbency Advantage and the Performance of Second Term Mayors', European Journal of Political Economy, 64.May (2020), 101910 https://doi.org/10.1016/j.ejpoleco.2020.101910

Lopez, Patricia J., and Abigail H. Neely, 'Fundamentally Uncaring: The Differential Multi-Scalar Impacts of COVID-19 in the U.S', Social Science and Medicine, 272.January

(2021),

113707 https://doi.org/10.1016/j.socscimed.2021.113707

Matthews, J.H., A. Forslund, M.E. McClain, and R.E. Tharme, 'More than the Fish: Environmental Flows for Good Policy and Governance, Poverty Alleviation and Climate Adaptation', Aquatic Procedia, 2 (2014), 16-23 https://doi.org/10.1016/j.aqpro.2014.07.004

McDonnell, R.A., K. Bergaoui, A. Khalaf, R. Zaaboul, and M. Belhaj Fraj, 'Impacting Policy: Harnessing Science on Climate Change and Water through Partnerships with Decision-Makers in the Middle East and North Africa Reflections', Aquatic Procedia, 2 (2014), 3-8 https://doi.org/10.1016/j.aqpro.2014.07.002 
McGill, Elizabeth, Vanessa Er, Tarra Penney, Matt Egan, Martin White, Petra Meier, and others, 'Evaluation of Public Health Interventions from a Complex Systems Perspective: A Research Methods Review', Social Science and Medicine, 272 (2021), 113697 https://doi.org/10.1016/j.socscimed.2021.113697

McGranahan, Gordon, 'Realizing the Right to Sanitation in Deprived Urban Communities: Meeting the Challenges of Collective Action, Coproduction, Affordability, and Housing Tenure', World Development, 68 (2015), 242-53 https://doi.org/10.1016/j.worlddev.2014.12.008

Morgan, P., 'Beneficial Partnerships in Rural Water Supply and Sanitation $\begin{array}{llll}\text { Reflections', } \quad \text { Aquatic } & \text { Procedia, 63-69 }\end{array}$ https://doi.org/10.1016/j.aqpro.2014.07.010

Muller, H., 'The South African Experience on Legal, Institutional and Operational Aspects of the Rights to Water and Sanitation', Aquatic Procedia, 2 (2014), 3541 https://doi.org/10.1016/j.aqpro.2014.07.006

Nightingale, Elana, and Chantelle A.M. Richmond, 'Reclaiming Mountain Lake: Applying Environmental Repossession in Biigtigong Nishnaabeg Territory, Canada', Social Science and Medicine, 272 (2021), 113706 https://doi.org/10.1016/j.socscimed.2021.113706

Patrick, M.J., H. Komakech, N. Mirumachi, H. Moosa, A. Prakash, L. Salame, and others, 'Building Bridges between the Sciences and the Arts of Water CoOperation through Collective Action - Reflections', Aquatic Procedia, 2 (2014), 48-54 https://doi.org/10.1016/j.aqpro.2014.07.008

Ravet, S., and A. Braïlowsky, 'Utilities' Contribution to the Human Right to Water and Sanitation: Importance of Stakeholders' Ownership', Aquatic Procedia, 2 (2014), 70-78 https://doi.org/10.1016/j.aqpro.2014.07.011

Ross, Ian, Oliver Cumming, Robert Dreibelbis, Zaida Adriano, Rassul Nala, and Giulia Greco, 'How Does Sanitation Influence People's Quality of Life? Qualitative Research in Low-Income Areas of Maputo, Mozambique', Social Science and Medicine, 272.January (2021), 113709 https://doi.org/10.1016/j.socscimed.2021.113709

Rotteveel, A. H., V. T. Reckers-Droog, M. S. Lambooij, G. A. de Wit, and N. J.A. van Exel, 'Societal Views in the Netherlands on Active Disinvestment of Publicly Funded Healthcare Interventions', Social Science and Medicine, 272 (2021), 113708 https://doi.org/10.1016/j.socscimed.2021.113708

Schnegg, Michael, and Theresa Linke, 'Living Institutions: Sharing and Sanctioning Water among Pastoralists in Namibia', World Development, 68 (2015), 205-14 https://doi.org/10.1016/j.worlddev.2014.11.024

Smith, Lisa C., and Lawrence Haddad, 'Reducing Child Undernutrition: Past 
Drivers and Priorities for the Post-MDG Era', World Development, 68.1 (2015), 180-204 https://doi.org/10.1016/j.worlddev.2014.11.014

Stevenson, Fiona A., Maureen Seguin, Geraldine Leydon-Hudson, Rebecca Barnes, Sue Ziebland, Catherine Pope, and others, 'Combining Patient Talk about Internet Use during Primary Care Consultations with Retrospective Accounts. A Qualitative Analysis of Interactional and Interview Data', Social Science and Medicine, 272 (2021), 113703 https://doi.org/10.1016/j.socscimed.2021.113703

Tadesse, Getaw, and Godfrey Bahiigwa, 'Mobile Phones and Farmers' Marketing Decisions in Ethiopia', World Development, 68 (2015), 296-307 https://doi.org/10.1016/j.worlddev.2014.12.010

Tinoco, M., M. Cortobius, M. Doughty Grajales, and M. Kjellén, ‘Water CoOperation between Cultures: Partnerships with Indigenous Peoples for Sustainable Water and Sanitation Services', Aquatic Procedia, 2 (2014), 55-62 https://doi.org/10.1016/j.aqpro.2014.07.009

Visser, Sanne Siete, and Hinke Haisma, 'Fulfilling Food Practices: Applying the Capability Approach to Ethnographic Research in the Northern Netherlands', Social Science and Medicine, 272.January (2021), 113701 https://doi.org/10.1016/j.socscimed.2021.113701

Zhu, Q., and Y. Li, 'Environmental Restoration in the Shiyang River Basin, China: Conservation, Reallocation and More Efficient Use of Water', Aquatic Procedia, 2.september 2013 (2014), 24-34 https://doi.org/10.1016/j.aqpro.2014.07.005 